\author{
Crossing the Border: International Journal of Interdisciplinary Studies \\ Volume 4; Number 1; 15 April 2016 \\ ISSN 2350-8752 (Print); ISSN 2350-8922 (Online)
}

\title{
JEALOUSY AND DESTRUCTION IN WILLIAM SHAKESPEARE'S OTHELLO
}

Ram Prasad Rai (Nepal)

\begin{abstract}
Othello is honest. He wants to establish an order and peace in the society. He falls in love with a white lady, Desdemona. Despite the discontentment of Desdemona's father Brobantio, they marry each other. Iago, an evil-minded man, is not happy with the promotion of Cassio, a junior officer to Iago, to lieutenant's post in support of the chief Othello. Iago becomes jealous to Cassio and plans to destroy the relation between Othello and Cassio in any way it is possible. He uses Roderigo, a rejected suitor to Desdemona and Emilia, the innocent wife of Iago in his evil plot. Iago treacherously makes Desdemona's handkerchief, a marriage gift from Othello, reach in Cassio through Emilia. Then he notices Othello about the Apresence of the handkerchief in Cassio as an accusation of Desdemona's falling in love with Cassio. In reality, both Cassio and Desdemona are innocent. They are honest and loyal to their moral position. But because of jealousy grown in Othello by Iago, Othello plans to murder his kind and truly loving wife and his dutiful junior officer Cassio. Othello kills Desdemona and Iago kills his wife Emilia as she discloses the reality about Iago's evilness. Othello kills himself after he knows about Iago's treachery. As a result, all the happiness, peace and love in the families of Othello and Iago get spoilt completely because of just jealousy upon each other.
\end{abstract}

KEYWORDS: Jealousy; suspicion; destruction; tragic end

Jealousy is an emotion that brings happiness, unhappiness and distress in someone's mind towards others' bad and good results. In fact, it is not good because it does not support to strengthen the co-operation between people. It brings problem in trust that one has for another as Salovey (2001) argues: "An individual in a relationship might become jealous as the person suspects that their significant other might have interest in someone else" (p. 1103). Jealousy causes dissatisfaction in a person upon others' goodness or success in any activity. When there is no happiness or satisfaction, there is no peace in one's mind like in the way Ekman (1992) states that a reasonably current list of the established basic emotions is: anger, fear, surprise, sadness, happiness, disgust and perhaps contempt (p. 550). It is clear that jealousy is also an emotion that inter-relates with the emotions mentioned by Ekman. Because of jealousy, the relation between the people is disturbed and the world of Othello is fully destroyed.

William Shakespeare uses various themes throughout his works such as love, revenge, death, betrayal, etc. His play Othello contains all these themes. However, the theme of jealousy seems to be the most prominent. Jealousy is prevalent in the characters from the very beginning of the drama. Roderigo is shown jealous of Othello and Iago of Cassio. Iago's involvement is strong to carry on the jealousy and creates a lot of suspicions in Othello 


\section{Crossing the Border: International Journal of Interdisciplinary Studies}

about Desdemona. The evilness and anger of Iago destroys the happiness of the couple Othello and Desdemona. The suspicion gets heightened and ends in Desdemona, Emilia and Roderigo's murder and the suicide of Othello himself. Iago has also to face his own great loss in life. In fact, the villainy of Iago gives birth to jealousy in Roderigo, suspicions in Othello upon his own innocent wife, Desdemona. This is what Knight (1930) declares: "It is true that Iago is here a mysterious inhuman creature of unlimited cynicism" (p. 97). This all leads the situation to a tragic end in the play. In this way, this article aims to make a complete study on how jealousy appears and develops in the drama destroying the lives of the characters.

From the early part of the drama Othello, Iago presents himself as an evil-minded person. The promotion of Cassio to lieutenant in army and his closeness to Othello, the General of the Army, upsets Iago. He is not happy and feels discriminated heavily. Then he starts weaving a plan to destroy Cassio. At the same time, Roderigo comes to fall to be a weapon in his evil plan. Since Roderigo fails to get the hand of Desdemona for marriage, he is in complete despair. When Othello marries Desdemona secretly without noticing Brobantio, the father of Desdemona, Roderigo is hurt. In fact, Roderigo has a feeling of love towards Desdemona despite being rejected by her. He has a jealousy against the relationship between Othello and Desdemona. Iago encourages Roderigo to disrupt the relationship between them by noticing it to Brobantio even in the night time as Iago says:

Call up her father;

Rouse him, make after him, poison his delight, Do; with like timorous accent and dire yell (I. i. 68 - 69, 75).

Iago desires to break the relation between Desdemona and Othello. So, he thinks that by informing Brobantio can be the best way to go for it. Roderigo is being used in this mission by lago.

In the article, "Doctor Iago's Treatment of Othello," Omer and Verona (1991) argue that Iago and Roderigo confront Brabantio about his daughter. Brabantio does not believe what the two say about Desdemona, calling it absurd, and becomes angry because he has been woken up in the middle of the night (p. 99). In this state of anger, Brobantio yells at Iago, "Thou art a villain," and in response Iago says, "You are - a senator" (I. i. 117-118). There is an irony in this response that even being a senator, he is failing to look after the situation of his daughter. It tries to say that Brobantio has to detect his daughter's activities in order to maintain his pride of being a father and a senator. In this context, Omer and Verona (1991) further argue: "This surprising comment causes Brabantio to step back and re-examine the situation, which eases his anger and causes him to believe the two, especially when he finds Desdemona missing from her bed chamber" (p. 99). But Brabantio has to remain quiet while Desdemona is producing her statement about her true love affair with Othello even in front of the Duke during the council meeting as she says:

My noble father,

I do perceive here a divided duty:

To you I am bound for life and education;

My life and education both do learn me

How to respect you; you are the lord of duty,

I am hitherto your daughter: but here's my husband (I. iii. 180-185).

Desdemona is very honest in her statement. She expresses the truth about her love towards Othello and her respect towards her father. So, without any fear, she says that it is her duty to serve both persons as her husband and father respectively. 


\section{JEALOUSY AND DESTRUCTION}

Iago is presented as a tactful as well as an unkind character in the play. He is clever enough about what to say and when to say it to get one to fall in his trap. In the article, "When Chaos Is Come Again: Narrative and Narrative Analysis in Othello," Macaulay (2005) observes Iago's manner: "Iago commences with an imperative, follows with a question in which he answers himself, and ends with a bold assertion" (pp. 261- 262). This is seen in how Iago creates false information about Othello's love to Desdemona when he says, "Mark me with what violence she first loved the Moor but for bragging and telling her fantastical lies; and will she love him still for prating? Let not thy discreet heart think it. Her eyes must be fed" (II. i. 220-224). In this statement, Desdemona is said to believe all the lies made by Othello. Iago says that Othello is only a liar to tempt Desdemona. Roderigo is manipulated wrongly about the relationship between Othello and Desdemona. This is all done by Iago only to excite the feeling of jealousy in Roderigo of Othello and Desdemona. This is like what Dobson and Wells (2001) state: "...but Iago, promising that her marriage to Othello will prove fragile, urges Roderigo to provide himself with money and come to Cyprus, understanding to help him cuckold the moor as part of his own revenge" (p. 331). The reality is that Roderigo is being a weapon for Iago to pollute the beautiful family of Othello.

Cassio is a very trustworthy soldier for Othello and he is promoted to the rank of lieutenant. Cassio is appointed to serve the General Othello. Iago is very much envious to Cassio's promotion as well as his good impression upon Othello. He thinks that he is more experienced than Cassio. Now, Iago plans to disrupt Cassio and urges Roderigo to work on it by giving him a hope of achieving the heart of Desdemona. In Cyprus, while guarding the General Othello, Iago makes Cassio drink a lot of alcohol as it is explained in what Mulherin and Frost (2005) opine:

Iago's chance comes that night. He and Cassio are waiting to go on guard, during a festival to celebrate Othello's wedding and his victory. At first, Cassio refuses to drink - he has a weak head. But soon Iago has every one singing songs and drinking. Cassio forgets his resolution, and drinks along with the rest just as Iago planned. (p. 148)

In fact, Iago is the grand designer of the evil plan to spoil Cassio, Othello, his position and his family. In this wicked process, Iago entraps whoever comes to be suitable to be used against Othello. He has already brought Roderigo into him and now he is using Cassio. This context is criticized by Greer (2002) when she further writes:

Iago's ubiquity in the play as he skips from character to character, organising the complicated scenario which will entrap Othello, is more than natural, as is his mad inventiveness in luring Roderigo and Cassio to their doom. To seduce Cassio he becomes the Morality character Good Fellowship, suddenly bursting into a wassail song. Cassio thinks that the devil who plays on him is wine, but Iago knows better. 'Come, come; good wine is a good familiar creature.... (II. iii. 296), (p. 54)

According to Iago's evil plan, now he has to present Cassio as a dishonest officer in front of Othello. That is why he wants Casssio to drink a lot and cause him to create some unfriendly situation. Iago makes him drink a lot.

Cassio gets involved in a brawl in his drunken mood. Because of this, next day, Othello demotes Cassio from his lieutenant's post. Iago is glad but pretends to have been worried about it in front of Cassio. Iago plans to create another false situation to harm both Cassio and Othello. He takes advantage of Cassio's upset moment and advises him to seek help from Desdemona to request Othello for the lost position back as Mulherin and Frost (2005) 


\section{Crossing the Border: International Journal of Interdisciplinary Studies}

assert: "Iago suggests he asks Desdemona to plead his case, Othello will refuse her nothing" (p. 148). When Cassio begins talking to Desdemona for this particular purpose, Iago takes this situation as an opportunity to pass a false message to Othello saying that Cassio is in love with Desdemona. Now, Othello is made suspicious about Cassio and Desdemona. In reality, both of them are innocent, but Othello does not understand them. Moreover, Desdemona's request to Othello for Cassio's reinstatement causes Othello to be more suspicious of them. Once Othello and Iago happen to see Cassio talking to Desdemona in private, Othello says, "Was not that Cassio parted from my wife?" In answer, Iago says, "Cassio, my lord?" (III. iii. 37-38). In this particular situation, Iago is trying to increase the strength of suspicion in Othello against Cassio and Desdemona's relation. While commenting on Iago's steps of ruining people, Omer and Verona (1991) observe: "Iago uses suspicions, hints, affirms by denying, cover his traces, forestalls criticism, and blurs the contours of reality" (p. 102). In fact, Iago keeps creating lies of Desdemona's unfaithfulness to make Othello highly jealous of Cassio and Desdemona.

By now Iago has completely changed Othello's perception of Cassio. Iago's main aim is to spoil the lives of both Cassio and Othello's family. Othello never tries to inquire his wife Desdemona and Cassio in order to know the reality about their relationship. He is fully manipulated by Iago. For this, Knight (1930) criticizes Othello's situation that the honoured warrior, rich in strength and experience, noble in act and repute, lies in a trance, nerveless, paralysed by the Iago-conception: "Work on, my medicine work" (IV.i.44), (pp. 117-118). What Iago says about Cassio and Desdemona, Othello believes without any queries. Othello knows from Iago that Desdemona's handkerchief is found with Cassio. Othello becomes completely obsessed by jealousy. Iago cleverly works behind the curtain now by misleading Othello ahead. Sometimes Iago pretends to be sympathetic towards Othello, but in reality, he is happy with what worries are going on in Othello's mind. Thinking that, Desdemona has deceived him, Othello changes his attitudes towards her.

In fact, Desdemona becomes Iago's focused point only in the latter part of the play. She is used in Iago's plot against Cassio and Othello. This also happens mainly when Iago is offended by Desdemona's questions upon Iago about his attitudes towards women. Moreover, in the process of dooming Cassio and Othello, Desdemona cannot remain untouched. She is also pulled into a wave of conspiracy of Iago. Her innocence is no more valued and respected by Iago's evil plan against Cassio and Othello, but her presence is used in order to make his project stronger ahead. Then Othello's jealousy of Cassio and Desdemona becomes extreme because of which Omer and Verona (1991) assert: "Othello becomes mad with rage and jealousy and Iago tries to redirect these powerfully strong emotions in false images which he constructs" (p. 109). Strengthening the jealousy in Othello, Iago says:

In sleep I heard him say, 'Sweet Desdemona,

Let us be wary, let us hide our love!' (III. iii. 420 - 421).

I know not that; but such a handkerchief -

I am sure it was your wife's - did I to-day

See Cassio wipe his beard with (III. iii. 438 -440).

This is all what Iago creates a fake thing about Desdemona and Cassio just to mislead Othello on his attitude towards his own wife. Othello cannot tolerate it and in extreme anger he yells at Iago, "'ll tear her all to pieces!" (III. iii. 433). He is extremely angry with his wife, Desdemona. Because of the gullibility towards Iago, Othello is violating his relationship with Desdemona as Knight (1930) explains: "This is the Iago spirit, the Iago-medicine, at work, like an acid eating into bright metal. This is the primary fact of Othello and therefore 


\section{JEALOUSY AND DESTRUCTION}

of the play. Something of solid beauty is undermined; wedged open so that it exposes an extreme ugliness" (p. 103). Here Iago is compared as acid that destroys the brightness of metal. Iago wants to ruin the beautiful world of Othello and Desdemona in any way he can. The handkerchief is the first gift of Othello for Desdemona. So, it is a very important object about their love relationship or husband and wife relationship. He does not know the reality about how the handkerchief reached Cassio. He is blinded by Iago's false interpretation about the handkerchief. But Mulherin and Frost (2005) state: "Iago continues to torment Othello, who is now half - mad with jealousy and completely in his power" (p. 150). Iago is not kind towards Othello's family, but he goes on thickening the jealousy in the mind of Othello against humble Cassio and Desdemona.

Now, Othello cannot maintain his patience any longer and plans to kill Desdemona and Iago is asked to kill Cassio. Iago pretends to wish a false consolation about such a plan and requests Othello to keep patience. But in response, Othello says:

Never, Iago...

Even so my bloody thoughts, with violent pace,

Shall neer look back, ne'er ebb to humble love,

Till that a capable and wide revenge

Swallow them up. (III. iii. 454, 458 - 461)

In fact, Othello does not know that he is being fooled by Iago. In his anger, Othello wants both Cassio and Desdemona to be killed. But Iago sends Roderigo to kill Cassio when both Roderigo and Cassio get wounded. Luckily Lodovico and Gratiano arrive there to see what has happened. Iago stabs Roderigo to death, because of the fear of getting his conspiracy disclosed by Roderigo.

In the meantime, thinking that Cassio has been killed, Othello goes to kill Desdemona as Mulherin and Frost (2005) describe:

Othello tells his wife to pray for forgiveness. When she asks him to explain, he accuses her of giving her handkerchief to Cassio. At last, Desdemona realizes that she and Cassio have been innocent victims of a plot, but the more she cries out, the more determined Othello becomes. She begs piteously for time - a day, half an hour, time to say a prayer, but Othello smothers her with a pillow. (p. 153)

Despite her pleading of being innocent and requests for a one more day life, she is stifled to death. This happens according to how Sabini and Silver (2005) comment: "What one means is that the jealous person wants to attack, is driven to attack, is eager to attack" (p. 703). Emilia is totally distressed. Othello repents a lot while knowing about Desdemona's innocence and the reality of Iago's villainy upon all from Emilia. In his extreme anger towards Iago, Othello tries to attack Iago as Mulherin and Frost (2005) state: "At last, Othello knows the dreadful truth. He finds his favourite sword and stabs Iago, but is prevented from killing him" (p. 153). He understands ultimately that he is fooled as he says, "O fool! fool! fool!" (V. ii. 323). He is in extreme pain because of his own error of judgment. Nothing is there to cure this pain at all. He feels he is totally collapsed for ever:

O cursed, cursed slave. Whip me, ye devils,

From the possession of this heavenly sight!

Blow me about in winds! roast me in sulphur!

Wash me in steep-down gulfs of liquid fire!

O Desdemona! Desdemona! dead!

Oh! Oh! Oh! (V. ii. 276-281)

He cannot tolerate his crime at all and commits suicide stabbing himself to death with his 


\section{Crossing the Border: International Journal of Interdisciplinary Studies}

sword. Emilia also really feels deceived by her husband Iago. What Iago has done that she knows is totally beyond her expectation. She accuses him of being a villain: "You told a lie, an odious damned lie. Upon my soul, a lie, a wicked lie" (V. ii. 178-179). Emilia is also murdered at the same time by Iago for disclosing all the reality. Iago is imprisoned.

In this way, Iago's false motivation causes the growth of jealousy one after another in Brabantio, Roderigo, Othello and in Iago himself. He is successful to manipulate each of the characters whoever he wants to use in his evil plan and cause such a disastrous event at the end. His evil act begins from the moment when he and his long experience are bypassed and Cassio is made a lieutenant by Othello. His aim is to create jealousy and anger in each of the characters like he has and destroys them. Iago is not sympathetic and helpful to Othello at all. His goal is only to destroy him. Bevington (2005) further describes that Iago succeeds in part because he is such a brilliant and resourceful manipulator of language, and because he knows where Othello is vulnerable (p. 169). Shakespeare presents such a villainous character, Iago, whose villainy causes the deaths of many people and his own downfall eventually.

\section{REFERENCES}

Bevington, D. (2005). Modern instances, misogyny, jealousy, pessimism, and midlife crisis. Shakespeare: The Seven Ages of Human Experiences (pp. 160-189). 2nd ed., Blackwell Publishing.

Dobson, M. \& Wells, S. (2001). Othello: The Oxford companion to Shakespeare (pp. 330335). New York. Oxford University Press.

Ekman, P. (1992). Are there basic emotions? Psychological Review, 99 (3), 550 -553.

Greer, G. (2002). Ethics- the nature of evil: Othello. Shakespeare: A Very Short Introduction (pp. 49-77). Oxford University Press.

Knight, G. W. (1930). The Othello music. The Wheel of Fire: Interpretation of Shakespeare's Tragedy (pp. 97-119). London: Oxford University Press.

Macaulay, M. (2005). When chaos is come again: Narrative and narrative analysis in Othello. Style, 39(3), 259 -272.

Mulherin, J. \& Frost, A. (2005). The best-loved plays of Shakespeare. 2nd ed. Cherry Tree Press Ltd. London.

Omer, H. \& Da Verona, M. (1991). Doctor Iago's treatment of Othello. American Journal of Psychotherapy, 45(1), 99-112.

Sabini, J. \& Silver, M. (2005). Ekman's basic emotions: Why not love and jealousy? Cognition and Emotion. Psychology Press, 19(5), 693-712.

Salovey, P. (1968). Sex differences in jealousy: Evolutionary mechanism or artifact of measurement? Journal of Personality and Social Psychology, 83(5), 1103-1116.

Shakespeare, W. (1968). Othello. Oxford: Oxford University Press.

\section{ABOUT THE AUTHOR}

Ram Prasad Rai received his Bachelor's degree from Ratna Rajya Laxmi Campus in Kathmandu and completed his Master's degree in English literature in 1997 from the University Campus, Tribhuvan University, Kirtipur. He took his M. Phil. degree from the Institute of Advanced Communication, Education, and Research (IACER) in Kathmandu under the Pokhara University in 2015. Currently, he is working as a Teaching Assistant at Ratna Rajya Laxmi Campus, Tribhuvan University in Kathmandu since 1999. He teaches English language and literature there. He has also taught English language and literature at KIST College and Prasadi Academy for six and nine years respectively.Email: ram_rai31@yahoo.com 